\title{
NAFTA in Mexico: What Worked? And What Did Not?
}

\author{
Dan Meylor ${ }^{1}$ and Kishore G. Kulkarni ${ }^{2 *}$ \\ 'Economics Major, Department of Economics, Metropolitan State University of Denver, \\ Campus Box 77, P. O. Box 173362, Denver, CO 80217-3362, United States of America \\ 2Distinguished Professor of Economics, Chief Editor, International Review of Business and Economics, \\ (www.irbejournal.com), Campus Box 77, P. O. Box 173362, College of Business, Metropolitan \\ State University of Denver, Denver, CO 80217-3362, United States of America
}

\begin{abstract}
Mexico joined the General Agreement on Tariffs and Trade in 1986 and less than a decade later joined the North American Free Trade Agreement (NAFTA) with the United States and Canada in 1994. Before these trade liberalizing moves, Mexico had hit a few bumps in the road when it came to stimulating economic growth. Unfortunately, the post NAFTA world and especially the COVID-19 world have only left more bruises on Mexico's economy. Most economists will agree that the Mexican economy is currently in struggling shape and that some positive effects of NAFTA did not help. The purpose of this paper is to point out the small handful of economic aspects from NAFTA that had a positive effect on Mexican Trade and the Mexican economy. After explaining each aspect of what worked and why it did not last, we will conclude with what we can learn from this and what can be changed looking forward.
\end{abstract}

Keywords: Free Trade, NAFTA Effects, Mexican Economy, Trade Agreements

\section{Introduction}

Prior to the 1980s, Mexico's economy was very different than the one we have seen over the last 10 years. Mexico was and technically is still a top oil exporter, the Bracero program that ended 1966 had begun to utilize the country's labor supply and the Mexican economy was semi-closed when it came to open the trade. While the unprecedented oil price increase helped the economic prosperity in 1970s, the following years were kind of turbulent. The economic bumps came from the oil crisis of 1982. This led to a fall in production, low wages, and a reliance on import substitutes. The opening of border trade with the U.S. and Canada was supposed to help the economic growth of Mexico however, the evidence is more like that of a country that is dependent on the United States and thus stuck by inability to compete in labor, agriculture, or regional growth. There are a handful of good things that did come from the joining of the North American Free Trade Agreement. Unfortunately, these economic spikes of growth and possibility were short lived. We refer to this period as the 'honeymoon' of NAFTA in Mexico.

\section{Literature Review}

Pablo Ruiz-Nápoles (2004) uses input-output analysis to look at the relations between Mexico's imports on economic growth, productivity, and employment. The parts of this research utilized are the history of trade liberalization of Mexico and overviews of productivity and employment through the eyeglass of North American trade relations.

${ }^{*}$ Author for correspondence 
Juan Carlos Moreno-Brid, and other contributors (2005) published work that examines the good and bad of the economic growth within post-NAFTA Mexico, along with policy suggestions in their work titled Industrialization and Economic Growth in Mexico after NAFTA: The Road Travelled. Points taken from this research include improvements of different industries post-NAFTA, historical information, and trade relation with United States.

Shyamalendu and Park (2001) explore the growth of trade between the United States and Mexico and the future implications of the trade deal. In this research I utilize the amount of growth seen in Mexico right after the implementation of NAFTA.

A congressional report titled NAFTA and the Mexican Economy (2008) revisits the effects on the Mexican economy and specifically the changes occurring in the agricultural sector. Along with the analysis of the agricultural sector, we examine the economic factors that plague the region.

Kulkarni and Schmidt (2014) analyze the trade relationship between the U.S. and Mexico. They utilize two important international models to analyze. From this research I incorporate the rise and fall of trade, growth, and labor within the country.

Bradley Condon (2018) writes in the work titled From NAFTA to USMCA: Two's Company, Three's a Crowd about the transition of U.S. President Donald Trump's view of NAFTA, how the new changes affect Mexico and the different views that Mexico and Canada take in relation to what the U.S. does. We utilize this evidence to show the present state of the Mexican economy and the point of disadvantage they have compared to the U.S. and Canada.

Romero (2020) summarizes the behaviors of the countries of NAFTA turned USMCA during the arrival of the COVID-19 pandemic. An overview is given of precautions taken regarding trade along with the questions of the future and the newly elected U.S. President Biden. Information utilized is the historical changes along with changes made to cross border change and its implications.

An article titled the COVID-19 Crisis and its effect on employment and poverty in Mexico (2020) analyzes the vast negative impact of the Corona virus on the Mexican economy. It is purpose in this research is to add historical context and relate it to on-going patterns.
A piece on the aftermath of North American trade in Mexico titled Did NAFTA Help Mexico? An update after 23 Years (2017) tells the story of trade and economic fault that occurred within the region. We utilize the historical information as well as the aspects of the wage change that occurred with relation to the labor market. Also used is the consensus of the Mexico being part of the trade block.

\section{Empirical Evidence}

\subsection{Market Access}

In the events of the world marketplace becoming smaller the benefits that Mexico saw from the access to different markets from being a part of NAFTA have been paying off even today. Mexico, while in a slump in the 1980s defined by slow growth, lower oil exports and negative growth in GDP, decided to join GATT, the General Agreement on Tariffs and Trade in 1986. This was one of the big moves that would be taken in what is called the trade liberalization of the country. After joining, in the next 4 years exports would grow by $14 \%$ and GDP by 3\% (Ruiz-Napoles, 2004). Joining the group of countries participating in easier trade as well as lowering tough restrictions that the country held onto for many years. This would eventually lead to the signing of NAFTA years later. After joining NAFTA in 1994, Mexico had large access to the most vital market on the planet, the United States. They also had access to Canada's, market but Canada was also taking whatever benefits they could get from the American relationship and historically has not had nearly as much trade with Mexico as with the U.S. The Mexican market as almost become like a little brother of the U.S. market in the way that wherever they go, we go. There is a reflective pattern that the two have specifically in the case of recessions, for example in the 1980's, 2001 and 2008 when the U.S. and the world were hit by economic shocks, Mexico was right there to absorb and feel the effects (Moreno-Brid, 2005). We will explain the unfortunate effects of this later. However, some can argue that the benefit to market access for Mexico is huge when it comes to relation with the U.S. Many of the banks in Mexico also became foreign owned which helped stabilize the financial system of the region (Moreno-Brid, 2005). What must be one of the largest benefits that the Mexico gets from open markets is the access to imports. The U.S. is 
the number one trade partner that Mexico has (Kulkarni, Schmidt, 2014). Along with the U.S. and Canada, Mexico has joined 12 other free trade agreements with 46 other countries (Trade.gov).

\subsection{Brief Growth}

The most important part of the NAFTA 'honeymoon' period is when there is growth that directly comes from the new agreement. Mexico had jumps in many different

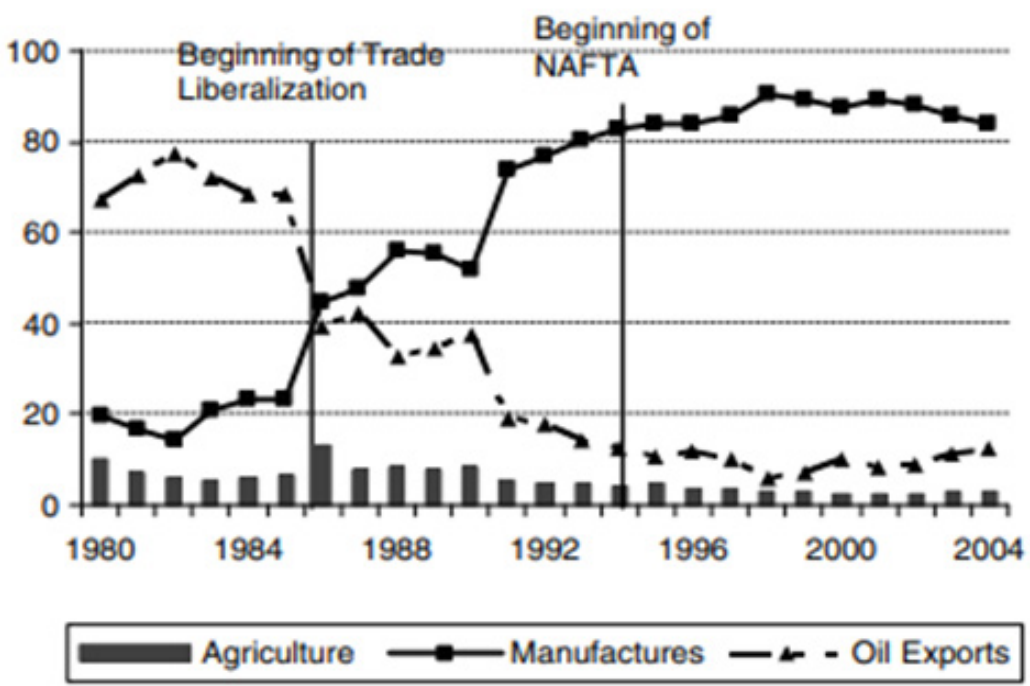

Note: Adapted from: World Bank. World Bank Indicators (2004)

Figure 1. Composition of Total Exports. Mexico 1980-2004 (\%).

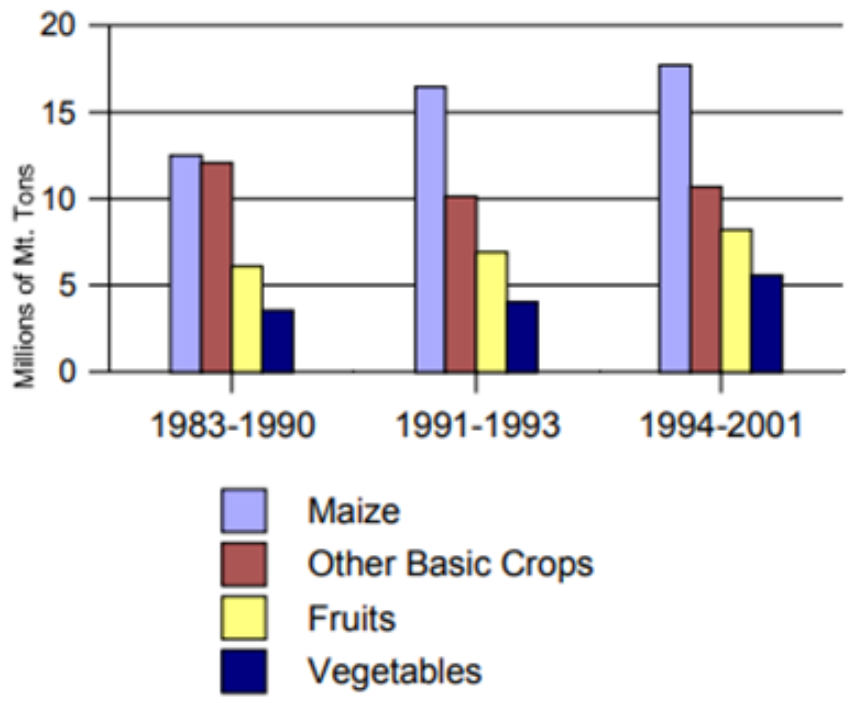

Note: Adapted from: Naude \& Taylor (2006).

Figure 2. Mexican Agriculture Production: Average Annual Averages. 
sectors after the signing of NAFTA. First, looking at international trade in general, Exports had 14\% growth the first five years after implementation (Ruiz-Napoles, 2004). Ten years after NAFTA, Mexico remains consistent in exports. Just five years after entering the agreement there was $126 \%$ growth in imports (Moreno-Brid, 2005). The export growth is in large part due to the Maquiladoras. These are factories set up on the Mexican side of the border where people from Mexico will produce final goods for American companies to export back to the U.S. with little travel costs. These factories set up before NAFTA was even considered, were the source of the growth in the manufacturing industry within Mexico. Many argue however, that the gains from NAFTA are skewed by the productivity of the already existent Maquiladoras and not accurately defined by such. Maquiladoras did however see higher growth after NAFTA than in the 80s (RuizNapoles, 2004). Manufacturing a huge piece of Mexican imports (Figure 1), but it stayed steady as agriculture declined (Moreno-Brid, 2005). Manufacturing is still one of Mexico's largest sectors today.

Agriculture on the other hand had a brief stint of growth. After NAFTA was signed, there was large growth in fruits, vegetables, and other staple crops (Figure 2). Eventually as we will talk about later, this did not last for long after the U.S. competed.

\subsection{Brief Wage Improvement}

A year after signing the agreement, the peso crashed in Mexico. This was very impactful, leading to unemployment

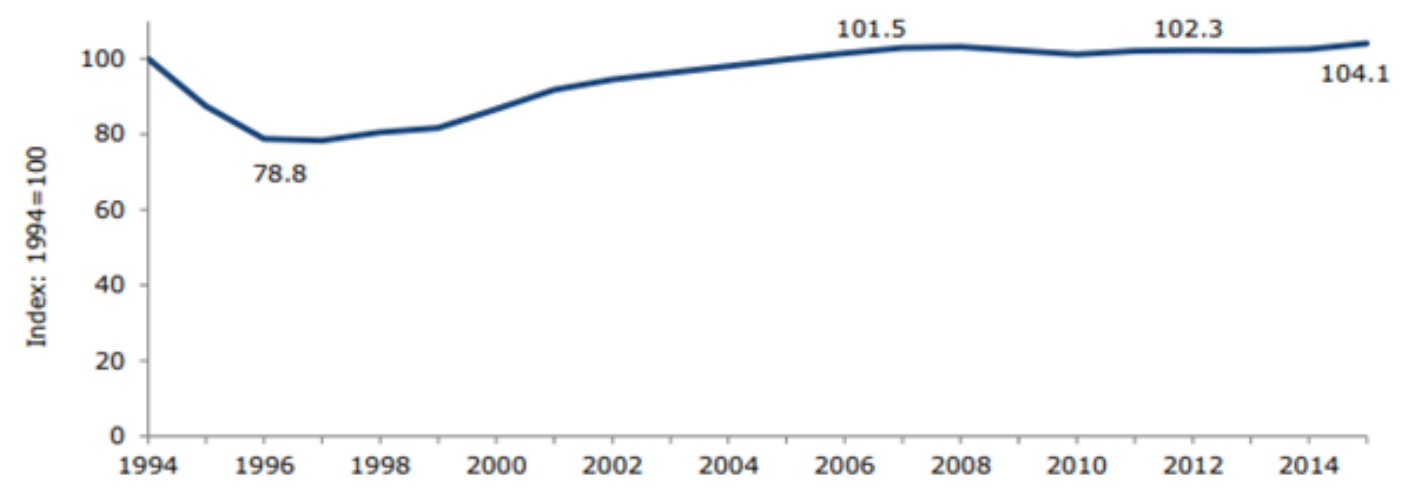

Note: Adapted from: ECLAC (2014).

Figure 3. México: Real Wages (1994-2014).

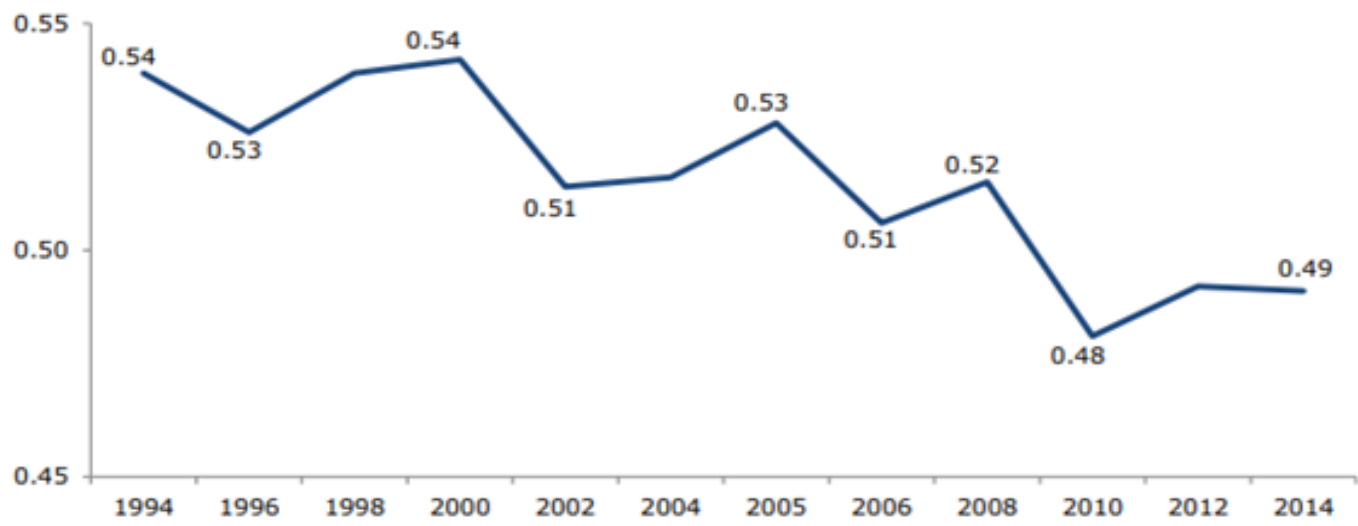

Note: Adapted from: ECLAC (2014).

Figure 4. Mexico: Gini Coefficient (1994-2014). 
and unfortunately massive declines in the economy. In most of the graphs I use in this paper there are dips and even scary looking ones right after 94 , that is because in 1995 the crash had a large impact and took many years to recover from.

One side of the crash did somehow lead to a small window where some growth occurred in the short run. When the peso declined there was really one good thing for trade that came of this crash. It was a spike in countries importing from Mexico because of cheaper prices. Because the wage and peso had collapsed, the price of these imports shrank and Mexico did see higher export numbers (Vilarreal, Marisabel, 2008).

Wages started to go up for everyday workers (Figure 3 ) with the increased exports and the wage distribution grew smaller and smaller. This is visible in the GINI coefficient (Figure 4). The lower the coefficient, the closer the wealth distribution. This is not necessarily the one and all solution, the effects of this would soon boomerang into another issue of which I will mention later.

\subsection{Role of Foreign Direct Investment (FDI)}

Finally, the largest impact and positive one that came directly after NAFTA and helped Mexico, was the growth resulting in Foreign Direct Investment or FDI (Figure 5). This occurs and takes many forms. Often this means the
U.S. buying office buildings or factories and hiring locally. NAFTA created a lot of funding programs to help bring foreign companies to Mexico. This is partially why the Maquiladoras were so successful they gave the average low skilled worker a job even if they lived in a smaller town. There are many issues that have come from this of which I will mention but, the post-NAFTA era has been spurred by enormous growth.

The influx of FDI did not only result in the success of Maquiladora facilities, but also in the industrialization of some of Mexico's largest cities such as Monterrey, Guadalajara and of Mexico City. The trade liberalization and signing of NAFTA made it very easy for countries to purchase office space and land in Mexico. With lower wages and large difference in exchange rate companies who come to Mexico from the U.S. can utilize the high supply of labor in the region bring their goods back to the U.S. duty free. This influx, however, became one of the main problems when it came to regional economic growth due to higher concentration in large cities.

\section{Summary and Conclusion}

As much as we would like to sing the praises of the NAFTA short term growth that occurred in Mexico. That would

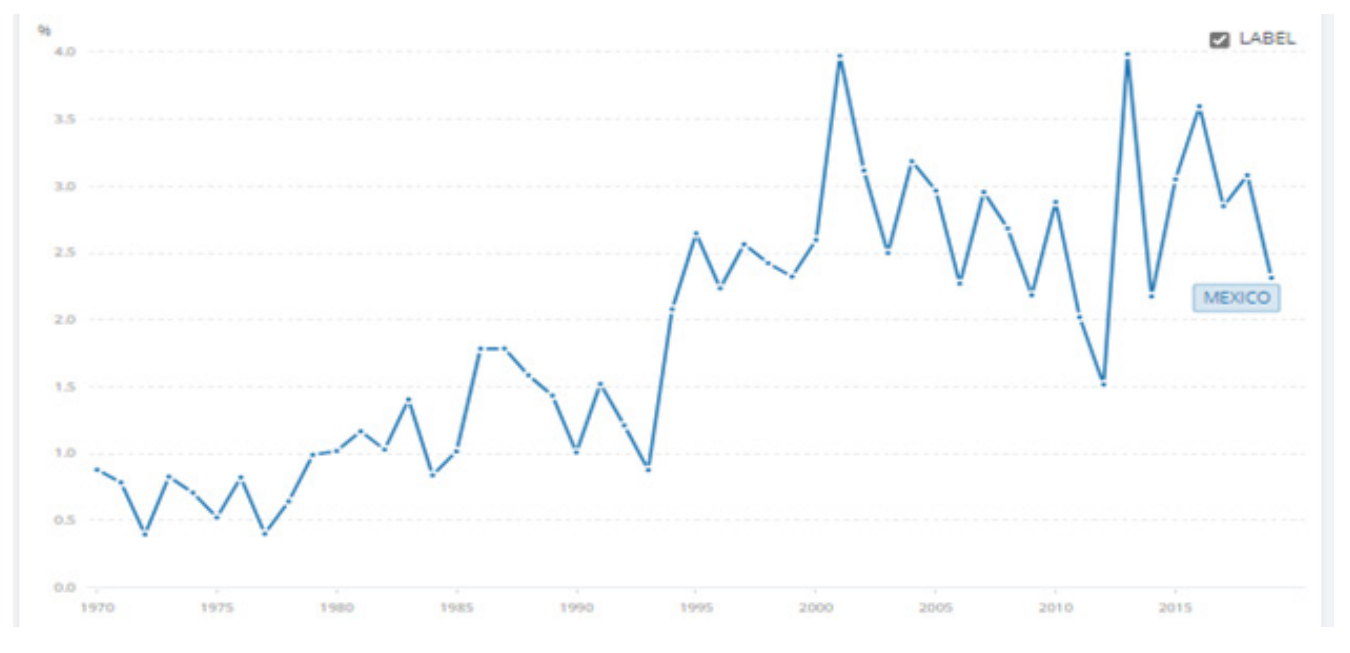

from: World Bank.

Figure 5. Foreign Direct Investment, Net Flows (\% of GDP) Mexico. 


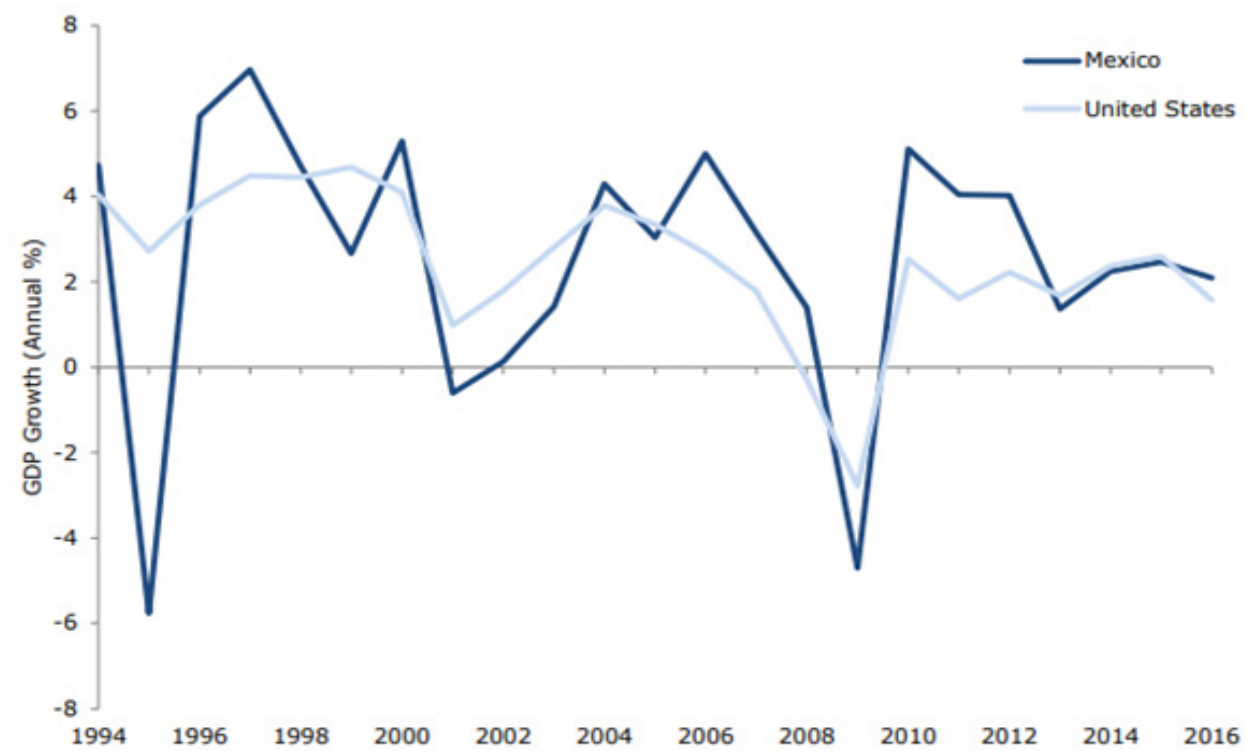

Adapted from: IMF (2016).

Figure 6. Mexico and the U.S. Annual GDP growth.

be only telling a very small part of the story. I started off with mentioning how Mexico not only had more access to foreign markets after NAFTA and throughout its time of trade liberalization, but it also mirrored the U.S. This is a good thing, but as with all economic perspectives, there are benefits and costs. The costs occur whenever there are any slight or massive recessions seen in the effect on GDP growth (Figure 6). These countries are basically following each other in the same pattern. Unfortunately for Mexico, it is affected by downturns harder given that she is a smaller country.

With respect to the labor market, access that the U.S. has from Mexico, both countries also compete for labor and unusually the U.S. wins. This is partially due to solid labor infrastructure, higher wage, and the use of unions. In the agricultural sector, there has been consistent growth thanks to the favorable natural resources that Mexico possesses.

Another issue arises when the U.S. offers subsidies for their farmers, they can go out compete with the farmers of Southern Mexico (Weisbrot, 2017). This loss of agricultural labor in the southern region has been huge in the battle against unemployment that has caused growth in the illusive informal sector and massive illegal immigration to the United States. During the time of higher wages, this put upwards pressures on export prices, and this led to loss of business to countries like China which has quickly become one of the United States' largest importing partners. The main issue surrounding FDI is that $65 \%$ of the investment is within only a handful of major cities that have grown due to the influx of foreign companies setting up shop there. Lastly catching up to modern times, the COVID-19 pandemic as left many of the citizens of the country in poverty (Meza, Hernández, 2020), leading, led to increase in wage disparity and not even the United States can answer the unknowns surrounding the virus. With the changes of the new USMCA agreement there is set to be more manufacturing going through the U.S. instead of Mexico. Things may not head in the direction that the country would like to see. If there are things to learn from this research it would be that to spur growth in these areas a few things could be changed. When it comes to competing with new markets, Mexico needs to invest into the increase of labor infrastructure to compete. Mexico would also need to start to replicate these manufacturing maquiladora facilities in different more rural areas which would help spur growth and attract more foreign investment. Many economists believe that to really grow Mexico would need to sustain a consistent $5-6 \%$ sustainable increase in 
GDP year after year (Moreno-Brid, 2005). However, not all the problems facing the Mexican economy are because of NAFTA (or USMCA) and only time will tell what will help, how things such as infrastructure could help economy prosper, and whether Mexico can come up with new policy to change her trajectory.

\section{References}

Condon, B. J. (2018). From NAFTA to USMCA: Two's Company, Three's a Crowd. Latin American Journal of Trade Policy 2 (Universidad De Chile). https://doi.org/10.5354/07199368.2018.52140.

Economic Commission for Latin America and the Caribbean (ECLAC). (2014). "Annual real average wages." "Gini coefficient."

Foreign Direct Investment, Net Inflows (\% of GDP) - Mexico. Data, data.worldbank.org/indicator/BX.KLT.DINV. WD.GD.ZS?locations $=$ MX.

International Monetary Fund (IMF). (2016). "World Economic Outlook, October 2016."

Moreno-Brid, J.C. et al. (2005). Industrialization and Economic Growth in Mexico after NAFTA: The Road Travelled. https://doi.org/10.1111/j.0012-155X.2005.00451.x.

Kulkarni, K. G., \& Schmidt, R. (2014). A partial test of the Heckscher-Ohlin-Samuelson Model: US-Mexico Trade Relations and Labor in Mexico. ANVESHAK-International Journal of Management. 3(1):11-13.
Mexico - Trade Agreements. International Trade Administration | Trade.gov, www.trade.gov/knowledge-product/mexicotrade-agreements.

Meza, D, \& Hernández J. S. (2020). The COVID-19 Crisis and its effects on employment and poverty in Mexico. Revista Internacional De Salarios Digno, 2(3):70-83.

Naude, Y., \& Taylor, J. E. (Author: 2006) The Effects of Nafta and Domestic Reforms in the Agriculture of Mexico: Predictions and Facts. Region Et Developpement, 23, 161-186.

Pablo, R. N. (2004). Exports, Growth and Employment in Mexico 1978-2000. Journal of Post Keynesian Economics, 27(1), 105-124.

Romero, A. S. (2020). From NAFTA to USMCA Negotiation. Signature of the Agreement and COVID-19 Pandemic. Observatório De Regionalismo (ODR).

Shyamalendu, S, \& Park, H. Y. (2001). Impact of the North American Free Trade Agreement on the U.S. Trade with Mexico. The International Trade Journal, p. 269-292. https://doi.org/10.1080/088539001753227992.

Vilarreal, A. M., \& Cid, M. (2008). Congressional Research Service, NAFTA, and the Mexican Economy.

Weisbrot, M, et al. (2017) Mar. Did NAFTA Help Mexico? An Update after 23 Years. Center for Economic and Policy, https://doi.org/10.22201/iij.24485306e.2018.1.12515.

World Bank. (2004). World Development Indicators. Available online: http://www.publications. worldbank.org/ecommerce/catalog/product?item_id=631625. 